\title{
On the Coordinated Development of Cultural Undertakings and Cultural Industries
}

\author{
Sui Baolu \\ School of political and social development, Zaozhuang University \\ Zaozhuang, Shandong Province, 277160 \\ E-mail: sbl630205@sina.com
}

\begin{abstract}
The article tries to show that cultural development requires the coordinated development of cultural undertakings and cultural industries. Because cultural undertakings and cultural industries are the two basic aspects of cultural development. And cultural undertakings provide resources and directions for the cultural industry. The cultural industry provides material support for cultural undertakings. Only when the two coordinates develop can the culture develop healthily. However, in the process of cultural development, there are many problems between the two aspects, which hinder the development of culture. To coordinate the development of cultural undertakings and cultural industries, these problems must be solved. In order to solve these problems, we must follow five basic principles in the process of cultural development and adopt four practical and feasible measures.
\end{abstract}

Keywords-China; culture; culture undertakings; culture industries; coordinated development

\section{INTRODUCTION}

Culture is not only a way of existence for a nation, but also an important manifestation of a country's overall national strength and influence. The development and prosperity of culture is the work that every nation and country is trying to do today. In the sixteen reports of our party, culture has been divided into public cultural undertakings and Operational Cultural Industries, how to define the boundaries of the two, how to deal with the dialectical relationship between the two, how to promote cultural development and prosperity, has become an important issue of the theoretical study. This text considers that cultural undertakings and cultural industries are the two basic aspects of Chinese cultural development. They are indispensable and must be coordinated develop based on the theory and system of cultural development, research results of experts and scholars and development of China's business and cultural industries of the Communist Party of China and Chinese Government.

\section{CULTURAL UNDERTAKINGS AND CULTURAL INDUSTRIES ARE THE TWO BASIC ASPECTS OF THE PROSPERITY AND DEVELOPMENT OF CULTURE}

Developing and flourishing the socialist culture with Chinese characteristics, insisting on the coordinated development of cultural undertakings and cultural industries, is the principles and policies that Communist Party of China

Author's introduction: Sui Baolu, male, 1963.2-, professor, mainly work in the study of Marx's philosophy principle and the Sinicization of Marx's Philosophy. always performs since the sixteenth national congress. The report of sixteenth national congress point out that, "In order to build a well-off society in an all-round way, we must vigorously develop socialist culture. "We should "actively develop cultural undertakings and cultural industries", "We should improve the policy of cultural industries and support the development of cultural industries". Subsequently "the decisions on some problems of perfecting socialist market economy system by the Communist Party of China" pointed out clearly, "We should change the functions of the administrative departments of culture and administration and promote the coordinated development of cultural undertakings and cultural industries. We should always put social benefits first and strive to achieve the unity of social and economic benefits". The seventeenth national congress also pointed out that, "In the current era, culture has become an important source of national cohesion and creativity, and has become an important factor in the overall national strength", the whole Party and the people of all ethnic groups should "promote the great development and prosperity of socialist culture", "raise up the socialist cultural construction". While promoting the reform of cultural undertakings, "we must rapidly expand the scale of China's cultural industries, make the proportion of cultural industries in the national economy increase significantly, and greatly improve international competition [1]. The fifth Plenary Session of the 17th CPC Central Committee, 18th CPC National Congress, resolutions and reports adopted in the third Plenary Session of the 18th CPC Central Committee, it repeatedly stressed the need to reform the socialist cultural system, we will energetically develop socialist cultural undertakings and cultural industries, we must persist the correct orientation, and make cultural undertakings and cultural industries coordinated develop. Especially "the decision of Central Committee of the Communist Party of China on deepening the reform of the cultural system, the decision to promote some major issues concerning the great development and prosperity of socialist culture", "Decision of Central Committee of the Communist Party of China on several important issues of deepening reform in a comprehensive way", and the essay Issued by the general office of the State Council Circular "on printing and distributing the two regulations governing the transformation of operating cultural institutions into enterprises and further supporting the development of cultural enterprises in the reform of cultural institutions" (General Office of the State Council(2014)No.15). It provides a clear direction and basic principles for the coordination of 
cultural undertakings and cultural industries to develop rapidly and stably.

To develop and prosper cultural undertakings and cultural industries, we must make clear the connotation, relationship and the state during cultural developing of cultural undertakings and cultural industries. We must make it clear that what the cultural industry is. "World cultural report cultural, creative and market", published by UNESCO in 1998, has defined culture industry, "Combining the creation, production and other ways to commercialize the essential intangible cultural content. These contents are protected by intellectual property rights and can be in the form of goods or services" [2] Ministry of culture of China has defined culture industry as "providing culture, products for entertainment and services to the public, and a collection of activities associated with these activities". Whether it is the definition of UNESCO or the definition of the Ministry of culture, the common point is that the cultural industry is determined to be productive, commodity and cultural. Accordingly, we may consider: the cultural industry mainly refers to the economic law and the law of value, adopts the mode of large-scale production and market operation, cultural production and cultural consumption activities aimed at achieving economic benefits and developing the economy. As for cultural undertakings, it is a concept with Chinese characteristics, it is the product of a planned economy, it is the original cultural management department and its subordinate cultural units. It refers to the government, engaged in research and writing in the field of culture, a general term for the organization of spiritual product production and cultural public services. Cultural undertakings undertake the function of providing public cultural services, with social benefits as the goal, without seeking economic benefits. Therefore, there are differences and connections between the two, and they infiltrate each other under certain conditions.

To be specific, the difference between the two is mainly manifested in the following aspects. First, the subject is different. The main body of cultural undertakings is the government departments, mainly engaged in public cultural products and services of the cultural institutions; the main part of the cultural industry is the production and sale unit of cultural goods, and it is an enterprise unit with juridical person. Second, different goals. Cultural undertakings to provide public cultural products and services to meet social and public needs, the pursuit of social benefits; Cultural industries provide cultural commodities and achieve economic benefits mainly through the market. Third, the operating mechanism is different. Cultural undertakings are mainly set up by the government, the government control it through the policies and regulations, cultural planning administrative directly; The cultural industry is market-oriented, taking the legal person company management mode, the government control it by law, tax policy, price leverage indirectly. Fourth, the source of funds is different. Different cultural undertakings funds mainly rely on state funding or social donations, sources of funds are single; the cultural industry funding is diversified, not only our nation, collective, but also individuals, foreign investment and other main investment, subject of investment.

The cultural undertakings and cultural industries is mainly manifested in the following aspects. At first, their goals are the same. Although the direct goals of cultural and cultural industries are different, Cultural undertakings pursues social benefits, the cultural industry pursues economic benefits. However, because the two belong to the culture, they have cultural attributes, they are the production of cultural products, and we must adhere to the principle of social efficiency as the leading factor. Therefore, the ultimate goal of the cultural industry is social benefits, it is only a unity of economic and social benefits. Second, the two depend on each other and interact with each other. Public service function ultimately depends on the spirit of products to complete, and needs some financial support to the spirit of the production of products, even state financial allocations or social donations depend on taxes and fees, and the economic or material wealth created by the cultural industry, it can not only meet the needs of some employees, but also provide material or financial support for the development of cultural undertakings; cultural industry production requires certain cultural resources and cultural originality, cultural undertakings need guidance and guide, otherwise they will lose the foundation and direction. Third, the two contain each other and infiltrate each other. In the actual field of culture, cultural undertakings and cultural industries can be united. As a matter of fact, many cultures, industries and fields are both public and economic. Taking modern media industry as an example, for its resources and spiritual products, it belongs to the public welfare cultural undertakings; in terms of the way it is operated, it belongs to the cultural industry because it requires economic benefits. Therefore, the two can not be completely separated [3].

Because of cultural undertakings and cultural industries are different, but interrelated, interdependent, interaction, indivisible, the two become the cultural foundation of existence and development, constitute the cultural development and prosperity of the "two legs". Culture provides the prosperity and development of culture resources, the cultural industry will provide direction the material basis and the way of cultural development.

\section{PROBLEMS EXISTING IN THE DEVELOPMENT OF CHINESE CULTURAL UNDERTAKINGS AND CULTURAL INDUSTRIES}

Although the Central Committee has always stressed that cultural undertakings and cultural industries must be strengthened, However, in many people's ideas and behavior, there are still errors that separate the two dialectical relations. In ideology, there is a "Pan ideological" and "Pan Industrialization" of culture. "Pan ideological "only expresses the ideology of culture. Emphasizing the social effects or functions of culture, neglecting or downplaying other cultural attributes, especially the industry, and opposing the industrialization of the cultural industries that can be industrialized, leading to cultural ossification and vitality. "Pan Industrialization "means that only thinking highly of the economic benefits of culture. Denying the social benefits of culture, we believe that all cultures should follow the road of industrialization, and excuse the development of market economy and ignore the public welfare of culture, resulting in lack of cultural products, cultural attributes, and the loss of government functions [4]. It is precisely because of "Pan industrialization" theory that lead to the development of 
cultural industries in the four major mistakes. These four mistakes can be summarized as "four much, four little": First is the "cultural industry accounted for the proportion of GDP, how to improve the quality of national culture"; Second is "cultural organization structure reform, culture content management system construction"; Third is "bigger and stronger cultural enterprises, support small and medium enterprises less about culture"; Fourth is "the industrial development, improving the education support system about"[5].

In the process of developing realistic cultural undertakings and cultural industries, there are also many unsatisfactory places.

In the development of cultural undertakings, it mainly concentrate in two aspects: first, cultural development is not balanced. This imbalance is two points: first, the imbalance between regions. The central cities and developed coastal areas have developed a lot of cultures, not only cultural talents, facilities, but also advanced cultural and cultural products; underdeveloped areas no matter talented persons, facilities, funding, or cultural level, cultural and spiritual products are inferior to the developed area. Second, the imbalance between city and countryside. Generally speaking, Because the city is the political, economic and cultural center of the region, the culture, public facilities, venues, funds and so on are more abundant than the rural areas, and relatively developed; In the rural areas, due to economic, transportation, information, ideas and other factors, cultural networks, cultural facilities, cultural funds, cultural talent, cultural resources, education, etc., are lacking, and cultural life is poor. Second, it lacks of cultural undertakings, the shortage of funds is still very outstanding. Although the state has increased its financial allocations for cultural undertakings, the amount of social donations has also increased; some cultural industries also feed back to the cause of culture, but because of the increase of head fees and labor costs, the funds for cultural undertakings are still in short supply, which affects the expansion and expansion of cultural undertakings.

In the cultural industry, the problem is mainly manifested in the following aspects. First, the mode of growth of cultural industry is extensive and low. The development of cultural industry is rapid and numerous, but the focus of growth is not content creativity, but production, it mainly rely on local nonmoving material cultural resources, such as local natural scenery, historical landscape, the development of celebrity resources, take the development of tourism as the main breakthrough, that is, cultural stage, economic singing. Hoping that through the ticket income, the surrounding land develop, real estate value-added, so the development of cultural industries is basically extensive [6]. Second, social benefits of cultural products are less. Whether it is film, television, radio, book publishing, drama, sketches and so on a large number of production, boutique scarce, shoddy, most of them are grandstanding; things that can cause people to recall, ponder, and admire are less, things that can go abroad and spread to other countries masterpieces are less. That is to say, a large number of cultural products that enter the market, more of them are short-term economic benefits, but lack of humanistic spirit and scientific spirit, social benefit is not high. Third, management system is poor, the operating mechanism is inactive. different industries of cultural industries belong to different authorities, resulting in the cultural industry is not conducive to the formation of lack of coordination, each department acting on its own, it is bad for the development of cultural market of cultural industry; because of the cultural industry belong to different departments, and some have been fully market-oriented, some are Semi Marketization, so in the process of market competition, market mechanism and planning mechanism are mutually staggered, even collide with each other, resulting in operating mechanism is not smooth, the efficiency is low.

Whether it is the concept of misunderstanding, or in practice, it will affect the development of cultural undertakings and cultural industries. Therefore, in order to truly develop culture and prosper culture, we must base ourselves on reality, identify the problems, and take measures to suit the remedy to the situation so as to coordinate the development of cultural undertakings and cultural industries.

\section{THE BASIC PRINCIPLES AND APPROACHES TO THE} COORDINATED DEVELOPMENT OF CULTURAL UNDERTAKINGS AND CULTURAL INDUSTRIES NEED TO BE ADHERED TO

"Decisions that the Central Committee of the Communist Party of China made to deepen the reform of the cultural system and promote the great development and prosperity of socialist culture", "Outline of the national cultural reform and development program in the "12th Five-Year" period", "Decisions about Several important issues of deepening reform in a comprehensive way that the Central Committee of the Communist Party of China made", "Circular on printing and distributing the two regulations governing the transformation of operating cultural institutions into enterprises and further supporting the development of cultural enterprises in the reform of cultural institutions", "Cultural industry revitalization plan", "Deepening the implementation of the cultural system reform program", such documents point out the principles and paths in order to realize the coordinated development of cultural undertakings and cultural industries.

The basic principles that should be adhered to in the coordinated development of cultural undertakings and cultural industries include:

First, "Adhering to the people oriented work orientation "which means adhering to the "people-oriented" principle. In the process of developing cultural undertakings and cultural industries, we must realize, maintain and develop the fundamental interests of the overwhelming majority of the people as a starting point and a foothold, firmly establishing the masses is the concept of cultural creation and construction of the main idea, no matter what culture undertakings or cultural industries, we must take people's satisfaction as the most important scale, a genuine, a boutique, a real product, everything for the people, everything depends on the people, let the people enjoy the fruits and make the people really satisfied.

Second, insisting on putting social benefit first, we should make great efforts to achieve social and economic benefits of the orientation that can not be changed, the position can not be 
lost. The principle of orientation can not be changed, Is to unswervingly implement the guidelines and policies of the party, principles and policies, adhering to the leading role of the socialist core values, adhering to the direction of socialist culture China, We can not take the old road, we can also not go astray; the position can not be lost, which refers to both public cultural undertakings and cultural industry, they should give full play to their vitality, make it become the leader and main force of carrying forward the advanced socialist culture and excellent traditional culture, that is to achieve the unity of social and economic benefits.

Third, adhering to the principle of unity of inheritance and innovation. Any country or nation has its own national cultural tradition, which is the foundation of a country and a nation that help its stand in the world, it is also the national spirit. China has rich historical and cultural treasures, there are many worldrenowned cultural heritage, and these are the resources that can not be neglected for the development of cultural undertakings and cultural industries, and it must be critically inherited. Of course, if we are totally enslaved to traditional culture without innovation, there is no future. Only on the basis of inheritance, innovation and innovation, we can create, invent, and progress in order to have a future and vitality.

Fourth, adhering to the principle of respecting the law. Whether cultural undertakings or cultural industries has a relatively independent law. Cultural undertakings must respect its relative independence of ideology, and the cultural industry has both the cultural side and the commodity side. As a culture, it must respect the cultural development as a commodity, it must respect the law; the law of value, competition law and the law of supply and demand. To develop and prosper culture, we must respect the regularity.

Fifth, adhering to the "please come in and go out" principle. Culture, as a manifestation of overall national strength, represents the influence of a nation or a nation. As a cultural undertaking, it is necessary to spread the national culture to other countries and peoples, let the world know China, understand China, expand the influence of Chinese, be more closer to the peoples of the world, which requires the culture to go out; one of the best ways to go out and spread the national culture is through the cultural market, that is, through the development and expansion of foreign cultural trade. Of course, any nation or country will bring in the culture of other countries and nations, enrich and develop the culture of its own nation, and enhance the vitality and competitiveness of its own national culture.

On the premise of adhering to the basic principles, exploring practical ways of development to make cultural undertakings and cultural industries, develop harmoniously, steadily and stably.

First, promoting the innovation of cultural system and mechanism, to co-ordinate cultural undertakings and cultural industries, stimulating the cultural creativity. This requires the relevant government departments to accelerate the improvement of cultural management system and cultural production and operation mechanism, promoting government departments to change functions, realizing the transformation from managing culture to managing culture, changing from a single administrative management to a comprehensive management rely on law, science and technology, economy; promoting the marketization of state-owned cultural enterprises, competing with other non - state cultural enterprises in the market equally and stimulating its cultural creativity; promoting the reform and expansion of cultural institutions, building efficient, standardized, responsible, high-quality operating mechanism in the market economy.

Second, balancing urban and rural basic cultural construction, making great efforts to build a modern public cultural service system. We should give full play to the public welfare function of cultural undertakings, take standardization, equalization, facilitation and modernization as the goal, constructing a modern public cultural service system covering both urban and rural areas, protecting the people's basic cultural rights and interests of watching television, listening to the radio, going to the Internet, reading books, reading newspapers, and cultural entertainment, we should improve the ideological, ethical and scientific and cultural qualities of urban and rural masses, especially rural residents, and improve the quality of services for public cultural undertakings.

Third, we must continuously enhance the overall strength and competitiveness of the cultural industry in order to build a modern cultural market system. In order to adapt to globalization and the development trend of science and technology, accelerating the strategic adjustment of the structure of cultural industry, Give full play to the leading role of cultural industry projects with a promising future; using local cultural resources, accelerating the development of cultural base, growing regional characteristics cultural industry; we should also give full play to the role of economic levers to support small cultural enterprises promising, improve its viability and competitiveness. That is to say, if we develop cultural undertakings and cultural industries, we should play the basic role of the market in the allocation of cultural resources, encourage market players a fair competition, the strongest live long, we should improve the scale, intensification and professionalism of the cultural industry and build a modern cultural market in line with the requirements of the market economy.

Fourth, we should improve cultural and economic policies, improve the cultural undertakings and cultural industry support, and meet the demand of funds for cultural development. Cultural development, prosperity, especially need financial support. In the shortage of funds under normal conditions, it especially needs economic policy support, such as investment and financing policies, supporting cultural enterprises listed financing and private capital into the culture, and absorb social capital into the cultural field. When it comes to fiscal policy, Introduce policies to encourage more enterprises and individuals to join in public cultural services. The cultural market access policy provides convenience for cultural enterprises, cultural occupations and cultural products access, and creates conditions for improving the market system. Reward or incentive policy, it support cultural creativity, creativity and innovation, and activate the cultural creativity of the whole nation. Preferential policies for foreign cultural exchanges and trade, such as export subsidies, tax rebates, etc., supporting state-owned private cultural enterprises and 
institutions to go out of the country, to the world, participating in international cultural competition, expanding the influence of Chinese culture, and enhance the right to speak Chinese culture.

\section{CONCLUSION}

In summary, cultural undertakings and cultural industries are two aspects of cultural development and cultural development is indispensable, "two legs", cultural needs development, prosperity, contradictions and problems must be solved between the two and themselves, that is to say, the two must be harmoniously developed. And the two must coordinate the laws and principles of cultural development in order to coordinate development, adopting practical measures conducive to cultural development, only the two develops harmoniously, cultural development and prosperity goals can be truly achieved.

\section{REFERENCES}

[1] Hu Jintao. "Holding highly the great banner of socialism with Chinese characteristics and strive for a new victory in building a moderately prosperous society in all respects"[N].People's Daily, 2007-10-25.

[2] Tan Hong. Discrimination between cultural undertakings and cultural industries[J].reform,2009 Sixth

[3] Zhou Zhenggang. Dialectical relation between cultural undertakings and cultural industries [J].Dong Yue Lun Cong, 2010 tenth.

[4] Du Xuewen. The relationship between cultural undertakings and cultural industries on the property [J].Shanxi University learned journal (edition of social siences), 2006 sixth.

[5] Qi Shuyu. Several key and difficult problems in current cultural construction [J].Administrative reform, 2013.1.

[6] Xiang Yong. The current situation and trend of China's cultural industry policy [N].Chinese Science Newpaperi, 2012.6.4. 